\title{
Alsidium oliveiranum sp. nov. (Rhodomelaceae, Rhodophyta), an overlooked species from the southwestern Atlantic based on morphology and DNA sequence data
}

\author{
Silvia M. P. B. Guimarães ${ }^{1}$, Luanda Pereira Soares ${ }^{1}$, Mutue Toyota Fujiii ${ }^{1}$ and \\ Pilar Díaz-Tapia ${ }^{2, *}$
}

${ }^{1}$ Institute of Botany, Nucleus for Research in Phycology, Av. Miguel Estéfano 3687, 04301-012 São Paulo, Brazil

${ }^{2}$ Coastal Biology Research Group, Faculty of Sciences and Centre for Advanced Scientific Research (CICA), University of A

Coruña, A Coruña 15071, Spain

The exploration of seaweed diversity in poorly studied habitats has often led to the discovery of new species. Sandcovered rocks are an example, as they received less attention than sand-free rocky intertidal habitats during seaweed diversity surveys in Brazil. In sand-covered rocks from Espírito Santo and Rio de Janeiro we found an alga whose morphology was unique among rhodomelacean species previously reported in Brazil. With the aim to clarify the taxonomic identity of this species we studied its morphology, as well as its phylogenetic relationships. Molecular analyses resolved this species in the genus Alsidium (tribe Alsidieae) and differed from sequenced congeners with divergences $\geq 2.5$ and $4.2 \%$ in the $r b c L$ and $\operatorname{cox} 1$ genes, respectively. Morphological characters were in agreement with the genus Alsidium, and differed from other species currently recognized in the genus. The species consisted of a basal crust and scarcely branched erect axes with seven pericentral cells covered by a continuous layer of cortical cells. Reproductive structures were formed on clusters of short determinate branches. Therefore, the new species A. oliveiranum is proposed based on morphological and molecular evidence. Our findings contribute to better understand the diversity of the tribe Alsidieae, which is particularly diverse in the Americas.

Key Words: Alsidieae; Brazil; Ceramiales; cox1; new species; rbcL; red algae; sand-covered rocks

\section{INTRODUCTION}

The family Rhodomelaceae includes 1,080 species classified in 158 genera (Guiry and Guiry 2019), and exhibit an extraordinary morphological diversity (Womersley 2003, Díaz-Tapia et al. 2017). Usually, members of this family are easily recognized by their thalli consisting on an axial filament whose cells are surrounded by pericentral cells and by the sympodial branching pattern (Womersley 2003). Moreover, most species in the Rhodomela- ceae have trichoblasts, apical monosiphonous branches that are usually unpigmented (Maggs and Hommersand 1993, Womersley 2003).

The Rhodomelaceae is the most diverse family of the red algae, and the number of recognized species is continuously growing. The discovery of new species is often related to the finding of cryptic diversity, both when comparing molecular data of specimens from dis-
(9) $\$$ This is an Open Access article distributed under the terms of the Creative Commons Attribution Non-Commercial License (http://creativecommons.org/licenses/by-nc/3.0/) which permits unrestricted non-commercial use, distribution, and reproduction in any medium, provided the original work is properly cited.
Received July 6, 2019, Accepted August 26, 2019

*Corresponding Author

E-mail:pdiaz@udc.es

Tel: +34-653535767, Fax: +34-981167065 
tant locations or from the same region (e.g., Zuccarello et al. 2015, Muangmai et al. 2016, Savoie and Saunders 2016, Díaz-Tapia et al. 2018, Schneider et al. 2018). More surprisingly, some species with conspicuous morphological differences regarding other members of the family remained unnoticed. One of the causes is that they grow in poorly explored habitats, such as the deep subtidal (Bárbara et al. 2013, Kim and Kim 2014). Intertidal sand-covered rocks are other common, more accessible, but often poorly explored habitat. The presence of sediments in intertidal rocks negatively affects many benthic organisms, and sand-covered rocks host a particular algal assemblage (Airoldi 2003, Díaz-Tapia et al. 2013a) in which several new red algal species have been recently described (Díaz-Tapia and Bárbara 2013, Díaz-Tapia et al. 2013b, D`Archino et al. 2015). During our surveys of marine red algae in this habitat along the coasts of Espírito Santo and Rio de Janeiro (southeastern Brazil), we found abundant populations of a rhodomelacean species consisting of large plants (up to $25 \mathrm{~cm}$ in length) with seven pericentral cells and a dense cortication from close to the apices. The morphology of this conspicuous species does not match with the species previously recorded in the region. Even its generic assignment was uncertain, as these characters resemble to some genera of the tribes Chondrieae, Alsidieae or Pterosiphonieae. The objective of this work is to clarify the taxonomic identity and phylogenetic relationships of the Brazilian species using molecular ( $r b c$ L and coxl genes) and morphological data.

\section{MATERIALS AND METHODS}

Plants of the targeted species were collected between 1986 and 2017 in Espírito Santo $\left(21^{\circ} 03^{\prime} \mathrm{S}, 40^{\circ} 52^{\prime} \mathrm{W}\right.$ to $19^{\circ} 52^{\prime} \mathrm{S}, 40^{\circ} 03^{\prime} \mathrm{W}$ ) and Rio de Janeiro (Praia Rasa; $22^{\circ} 44^{\prime}$ $\mathrm{S}, 41^{\circ} 57^{\prime} \mathrm{W}$ ) from the intertidal zone or in the drift (see material examined and Supplementary Table S1). Samples preserved in silica gel desiccant, collected in 2006 and 2014, were used for DNA extraction. Plants for morphological studies were fixed in $4 \%$ formalin in seawater. Sections for anatomical studies were made by hand using a razor blade and stained in $1 \%$ aqueous aniline blue acidified with $1 \mathrm{~N} \mathrm{HCl}$. Sections were photographed on Ilford 50 ASA film (Harman Technology Ltd., Cheshire, UK) with an Olympus BH-2 photomicroscope (Olympus Corporation, Tokyo, Japan). Representative material was deposited in the SP (Institute of Botany) herbarium, São Paulo, Brazil.
DNA was extracted from silica gel-dried material following Saunders and McDevit (2012). Polymerase chain reaction (PCR) amplification was carried out for $r b c \mathrm{~L}$ using the primers F2/R1452, F7/RrbcsStart, F7/R893 or F57/rbcLrevNEW (Freshwater and Rueness 1994, Mamoozadeh and Freshwater 2011, Saunders and Moore 2013, Díaz-Tapia et al. 2018) and for coxl using the primers GwsFn/Cox1R1 (Saunders 2008, Le Gall and Saunders 2010) or GazF1/GazR1 (Saunders 2005). Reactions were performed in a total volume of $25 \mu \mathrm{L}$, consisting of $5 \mu \mathrm{L}$ $5 \times$ MyTaq reaction buffer, $0.7 \mu \mathrm{L} 10 \mu \mathrm{M}$ of forward and reverse primers, $0.125 \mu \mathrm{L} 1 \mathrm{U} / \mu \mathrm{L}$ My Taq DNA Polymerase (Bioline, London, UK), $17.475 \mu \mathrm{L}$ MilliQ water and $1 \mu \mathrm{L}$ template DNA. The PCR profile consisted of initial denaturation $\left(93^{\circ} \mathrm{C}\right.$ for $\left.3 \mathrm{~min}\right), 35$ cycles of denaturation $\left(94^{\circ} \mathrm{C}\right.$ for $30 \mathrm{~s})$, primer annealing $\left(45^{\circ} \mathrm{C}\right.$ for $\left.30 \mathrm{~s}\right)$, and extension $\left(74^{\circ} \mathrm{C}\right.$ for $\left.90 \mathrm{~s}\right)$ and final extension $\left(74^{\circ} \mathrm{C}\right.$ for $\left.5 \mathrm{~min}\right)$. The PCR products were purified and sequenced commercially by Macrogen (Seoul, Korea).

Two sequences were generated in this study for the targeted species for each gene ( $r b c \mathrm{~L}$ and $c o x 1)$, and blast search in GenBank for the $r b c \mathrm{~L}$ sequences of the Brazilian unidentified species indicated Alsidium seaforthii (Turner) J. Agardh, in the tribe Alsidieae, was that the most similar species (similarity 97.23\%). Therefore, we downloaded from GenBank all the available $r b c \mathrm{~L}$ and cox 1 sequences for species of the tribe Alsidieae. We also determined five and ten new $r b c \mathrm{~L}$ and $c o x 1$ sequences for species of the genus Alsidium C. Agardh from Brazil, the Canary Islands and the Mediterranean Sea (Supplementary Table S1). We selected 17 sequences, one per haplotype, for the $r b c \mathrm{~L}$ and $c o x 1$ phylogenetic analysis. When several sequences were available for a haplotype, we selected the largest. Sequences and their corresponding GenBank accession numbers are listed in Supplementary Table S1. Sequences were aligned using Muscle in Geneious 6.1.8 (Kearse et al. 2012). Phylogenetic trees for $r b c \mathrm{~L}$ and $c o x 1$ were estimated with maximum likelihood (ML) using RAxML 8.1.X (Stamatakis 2014). GTR-Gamma was used as the nucleotide model; branch support was estimated with 100 bootstrap replicates. The genera Chondria C. Agardh and Acanthophora J. V. Lamouroux (tribe Chondrieae) were selected as outgroup for the $r b c \mathrm{~L}$ and cox 1 trees, respectively. Our outgroup selection was based on the phylogenomic analyses of the major lineages of the Rhodomelaceae that resolved a clade formed by the Chondrieae and Laurencieae as sister to the Alsidieae (Díaz-Tapia et al. 2017). 


\section{RESULTS}

\section{Phylogeny}

The RAxML phylogenetic analysis of $r b c \mathrm{~L}$ sequences (Fig. 1) placed a unique Brazilian species of Alsidium in a fully supported clade that included other species of the genus. Within this clade the Brazilian species was placed as sister to A. seaforthii, but this relationship was unsupported. The Alsidium clade was sister to the fully supported Digenea C. Agardh clade. The cox1 tree (Fig. 2) had a similar topology than the $r b c \mathrm{~L}$ tree. In the coxl tree, the Brazilian species was placed as sister to the generitype Alsidium corallinum C. Agardh, but again, this relationship was unsupported.

Two $r b c \mathrm{~L}$ and $c o x 1$ sequences for the new Brazilian Alsidium were identical. Seven $r b c \mathrm{~L}$ sequences for $A$. corallinum from the Mediterranean Sea (three) and the Canary Islands (four) were identical. Likewise, four cox 1 sequences of A. triquetrum (S. G. Gmelin) Trevisan, from Mexico and Brazil, were identical. A. seaforthii from Brazil was genetically more diverse in the $\operatorname{cox} 1$ gene, and four haplotypes that diverged by $0.1-2 \%$ (1-14 bp) were discovered for the species. Sequence divergence between the Brazilian species and other species of the genus $A l$ sidium, was $\geq 2.5$ and $4.2 \%$ in the $r b c \mathrm{~L}$ and $c o x 1$ genes, respectively. These findings allow for the description of a new species of Alsidium from Brazil.

\section{Morphological observations}

\section{Alsidium oliveiranum S. M. Guimarães \& M. T. Fujii sp. nov. (Figs 3-5)}

Diagnosis. Thallus consisting of a basal crust, from which many cylindrical, erect branches are formed. Erect branches up to $1 \mathrm{~mm}$ in diameter, with seven pericentral cells and heavily corticated from close to the apices. Vegetative trichoblasts scarcely developed if present. Reproductive structures formed on clustered determinate lateral endogenous branches. Spermatangial branches formed on modified trichoblasts and replacing them, consisting of thin, flat discs, lacking marginal sterile cells. Cystocarps globose. Tetrasporangia spirally arranged on fertile branches, one per segment.

Holotype. SP470454, Sep 10, 2014, M. T. Fujii \& P. DíazTapia, sand-covered rocks in the low intertidal.

Type locality. Praia da Cruz; Marataízes, Espírito Santo, Brazil.

Etymology. Named in honor of Dr. Eurico Cabral de Oliveira $F^{\circ}$, from the University of São Paulo, for his con- tributions to our understanding of the Ceramiales from Espírito Santo, Brazil.

Molecular vouchers. MN165085 rbcL, MN165073 cox1.

Other specimens examined. Espírito Santo: Aracruz County, Praia dos Padres, Oct 22, 1996, S. M. P. B. Guimarães \& M. T. Fujii, SP470448. Serra County, Praia da Baleia, Sep 17, 1986, S. M. P. B. Guimarães, SP470447. Anchieta County, Praia de Parati, Jul 20, 1997, S. M. P. B. Guimarães \& M. T. Fujii, SP470449; Oct 4, 2006, M. T. Fujii, SP470451; Sep 8, 2014, M. T. Fujii, SP470452. Anchieta County, Ponta dos Castelhanos, Sep 9, 2014, M. T. Fujii, SP470453. Itapemirim County, Praia de Itaoca, Oct 5, 2017, L. P. Soares, SP470455. Marataízes County, Praia da Cruz, Sep 10, 2014, M. T. Fujii, SP470454; Praia de Marataízes, Sep 15, 2001, S. M. P. B. Guimarães \& M. T. Fujii, SP470450. Rio de Janeiro: Armação dos Búzios Country, Praia Rasa, Oct 24, 2011, M. T. Fujii, SP470467.

Habitat and distribution. Plants grow up in tufts forming dense intertidal populations in Espírito Santo and Rio de Janeiro, southeastern Brazil (ca. 20 ${ }^{\circ} \mathrm{S}$ ), growing on sandstone beach reefs or on rocky outcrops often buried by sand and subjected to moderate water movement. Plants were also collected in the drift.

Vegetative morphology. Thalli consisted of a basal crust $2-3 \mathrm{~cm}$ in diameter bearing tufted erect axes up to $25 \mathrm{~cm}$ high and $1 \mathrm{~mm}$ in diameter (Fig. 3A \& B). Erect axes terete, scarcely branched alternately to irregular, and bearing clusters of short determinate endogenous lateral branches. Thallus not adhering to herbarium paper when dried; rigid and red to reddish-brown or wine-red in color. Erect axes with polysiphonous structures and heavily corticated. Apical cell of erect axes dome-shaped, 17-25 $\mu \mathrm{m}$ in diameter, dividing transversely forming axial cells which divided longitudinally producing the pericentral cells (Fig. 3C). Branches of vegetative axes formed endogenously close to the apices (Fig. 3G). Cortication developed from close to the apices, initially formed by divisions at the margins of the pericentral cells. Later, the cortical cells formed a continuous layer, so that the pericentral cells were only visible in surface view at the apices. In surface view, cortical cells in middle portions of thalli were rounded to polygonal, 15-55 × 17-98 $\mu \mathrm{m}$ (Fig. 3D). In cross-section (Fig. 3E), thallus consisted of an axial cell, seven rounded to polygonal pericentral cells, 123-250 $\mu \mathrm{m}$ in diameter, a layer of medullary unpigmented rounded to polygonal cells, $115-150 \mu \mathrm{m}$ in diameter, and an outer layer of pigmented and rounded to rectangular cortical cells, $27-100 \mu \mathrm{m}$ in diameter. Secondary pit connections formed between adjacent outer cortical cells. In longitudinal section, pericentral cells 


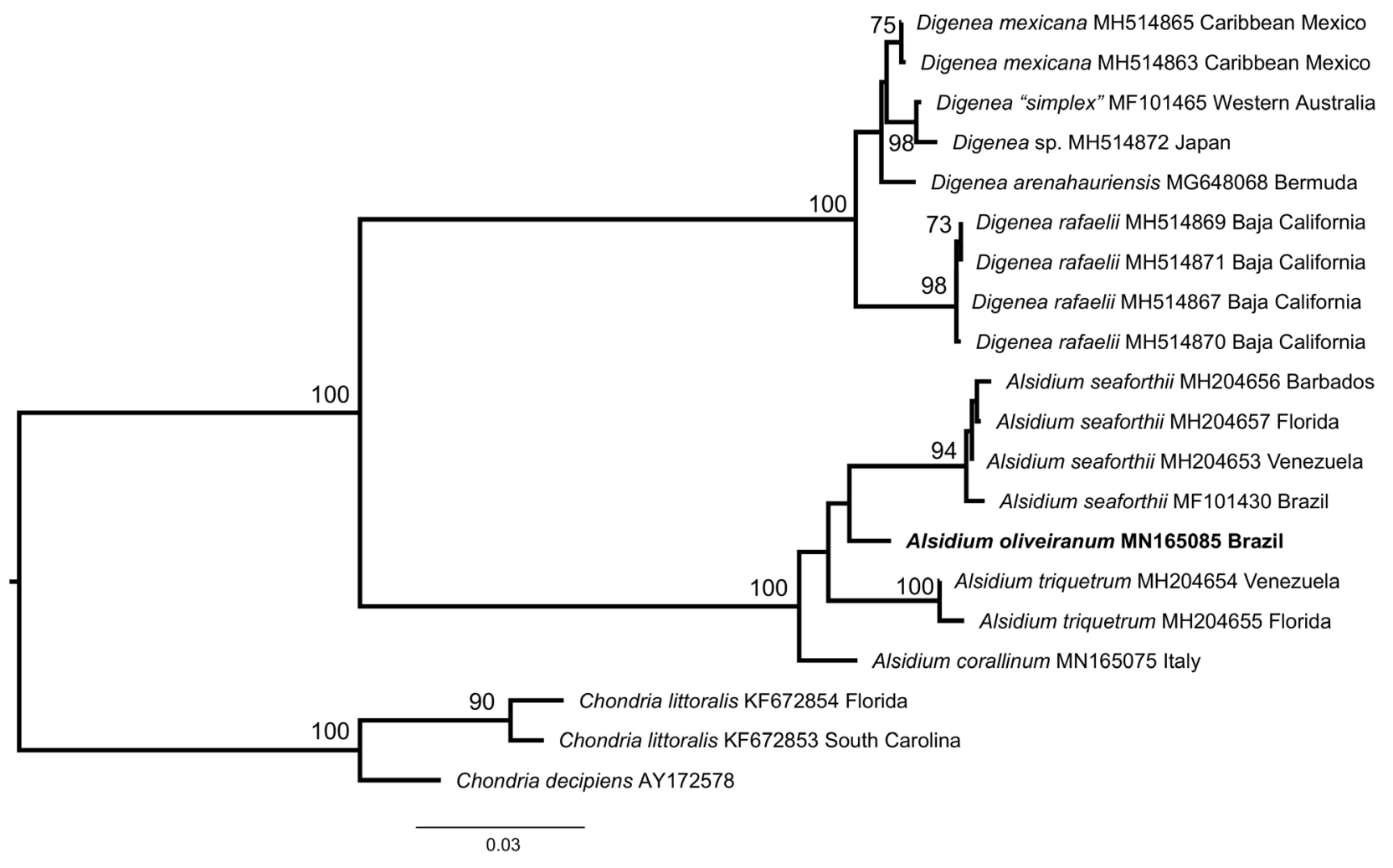

Fig. 1. Phylogenetic tree estimated with maximum likelihood analysis of $r b c \mathrm{~L}$ sequences. Values at nodes indicate bootstrap support (only shown if $>70$ ).

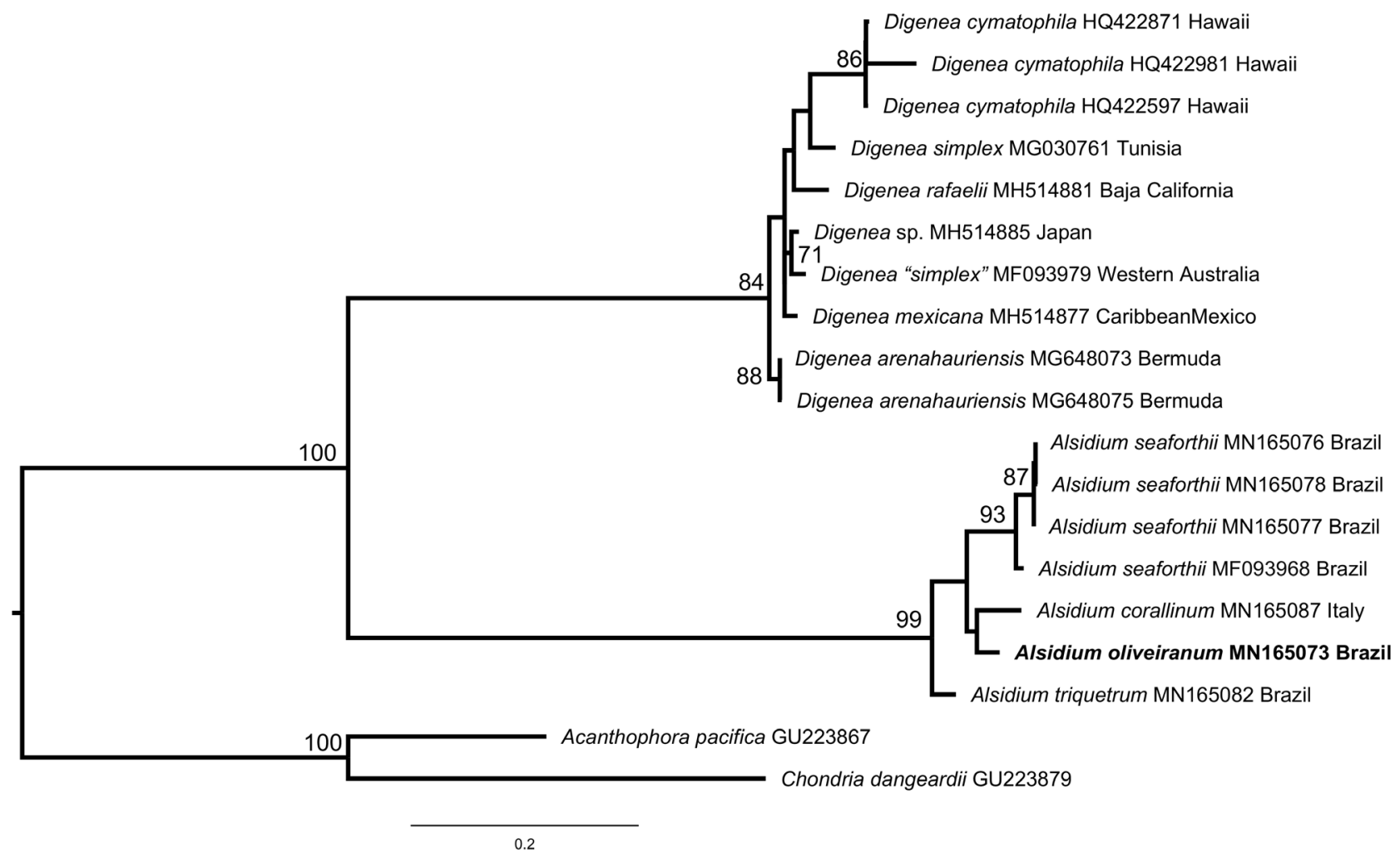

Fig. 2. Phylogenetic tree estimated with maximum likelihood analysis of cox 1 sequences. Values at nodes indicate bootstrap support (only shown if $>70$ ). 


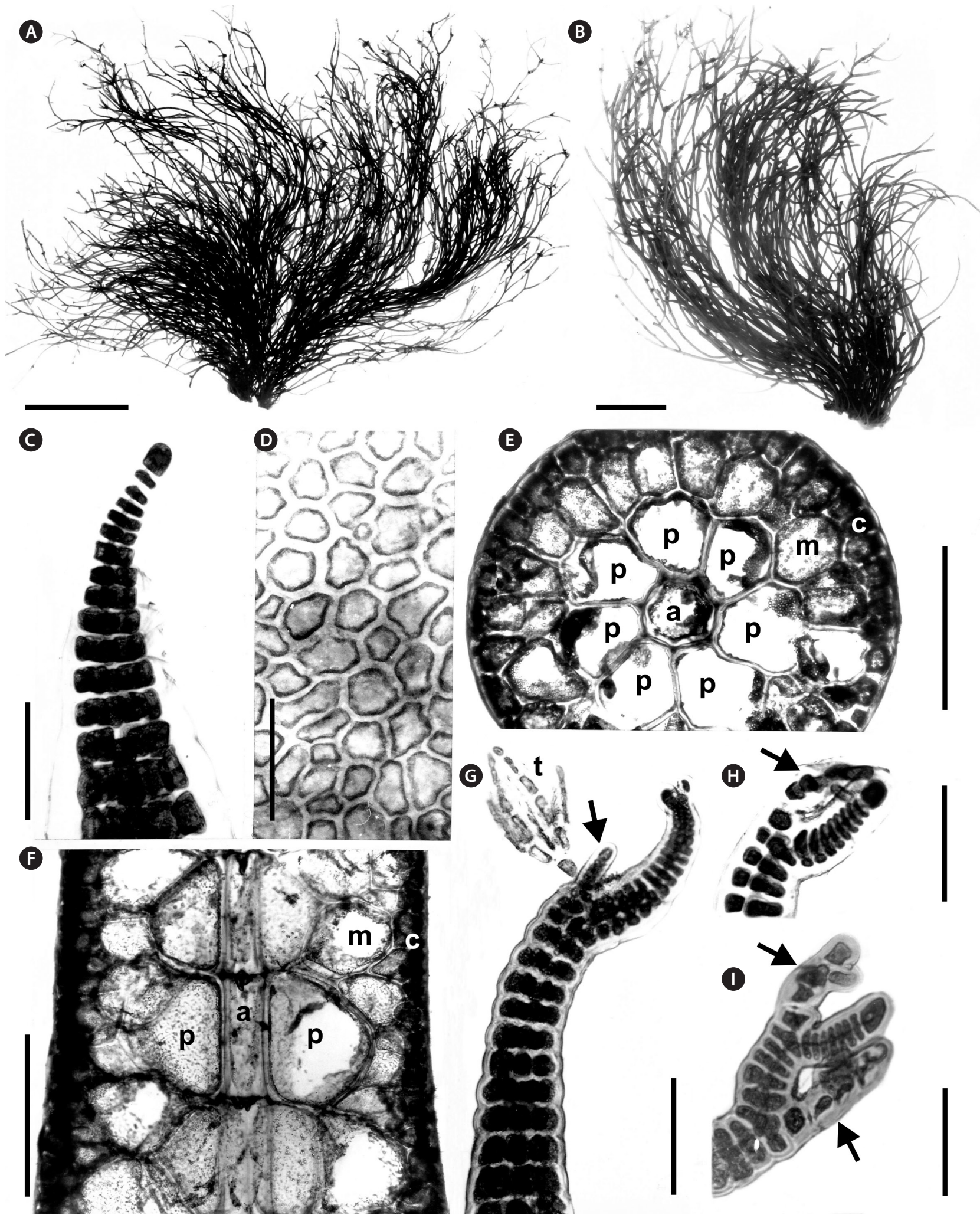

Fig. 3. Alsidium oliveiranum sp. nov. (A \& B) Habit of tetrasporangial plants. (C) Apex of a branch with a domed-shaped apical cell. (D) Surface view of cortical cells. (E \& F) Cross (E) and longitudinal (F) section of an axis showing the central-axial cells (a), pericentral cells (p), medulla ( $m$ ), and cortex (c). (G) Apex of a vegetative axis with a trichoblast (t) and an endogenous lateral branch (arrow). (H \& I) Upper portions of vegetative axis with short trichoblasts (arrows). Scale bars represent: $A, 4 \mathrm{~cm} ; \mathrm{B}, 2 \mathrm{~cm} ; \mathrm{C}, \mathrm{H} \& \mathrm{I}, 50 \mu \mathrm{m} ; \mathrm{D} \& \mathrm{G}, 100 \mu \mathrm{m} ; \mathrm{E} \& \mathrm{~F}, 300 \mu \mathrm{m}$. 

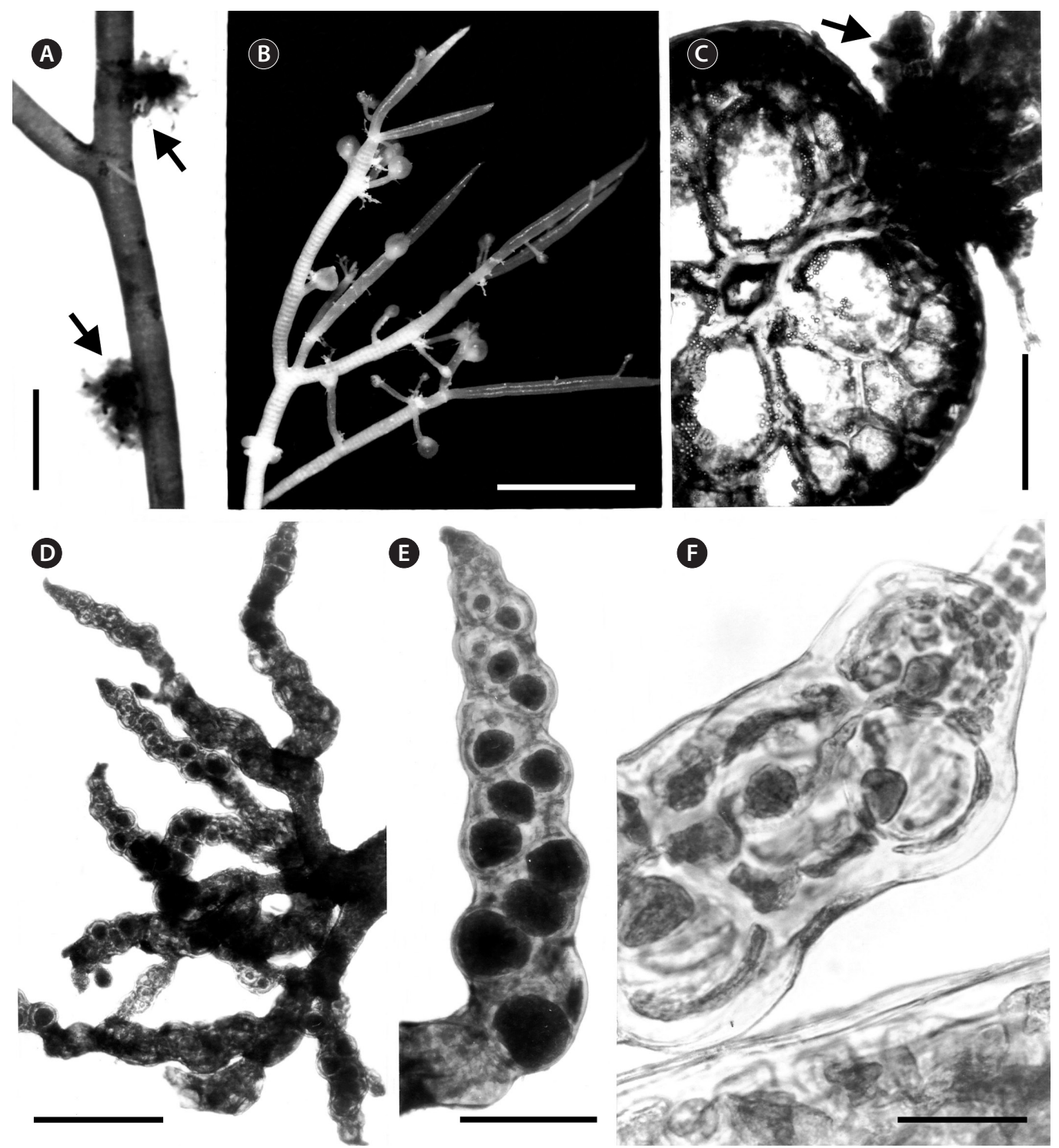

Fig. 4. Alsidium oliveiranum sp. nov. (A) Axis of a tetrasporophyte with clusters of tetrasporangial branches (arrows). (B) Female gametophyte with mature cystocarps. (C) Cross-section of a young axis bearing endogenous tetrasporangial branches (arrow). (D) Cluster of tetrasporangial branches. (E) Tetrasporangial branch bearing spirally arranged tetrasporangia. (F) Young tetrasporangia. Scale bars represent: A, 2 mm; B, 5 mm; C $\& E, 200 \mu m ; D, 500 \mu m ; F, 50 \mu m$.

were rounded to polygonal, with the same length as axial cells (Fig. 3F). Lateral endogenous determinate branches scarce, forming clusters. Trichoblasts rare, formed at the apices of young vegetative branches when present; short, to $140 \mu \mathrm{m}$ long, and dichotomously branched 1-2 times (Fig. 3G-I).

Reproductive morphology. Reproductive structures produced on lateral endogenous branches (Fig. 4A-D). Spermatangial branches consisted of thin, flat discs, lacking sterile marginal cells and replacing trichoblasts. In fertile female plants, procarps formed on modified trichoblasts on the adaxial side of short determinate laterals in a spiral pattern (Fig. 5A \& B). Few short vegetative and reproductive trichoblasts present on young female branchlets (Fig. 5D \& E). The entire pericarp seems to develop from the third and fourth pericentral cells of the fertile segment (Fig. 5C). Mature cystocarps globose, c. $1 \mathrm{~mm}$ in diameter, corticated, slightly flat at the top and with an apical ostiole (Figs 4B, 5F \& G). Owing to its growth, mature cystocarps become distal on a short lateral branchlets. Apical portions of branchlets can be observed as ligulate appendices (Fig. 5F). Tetrasporangial 

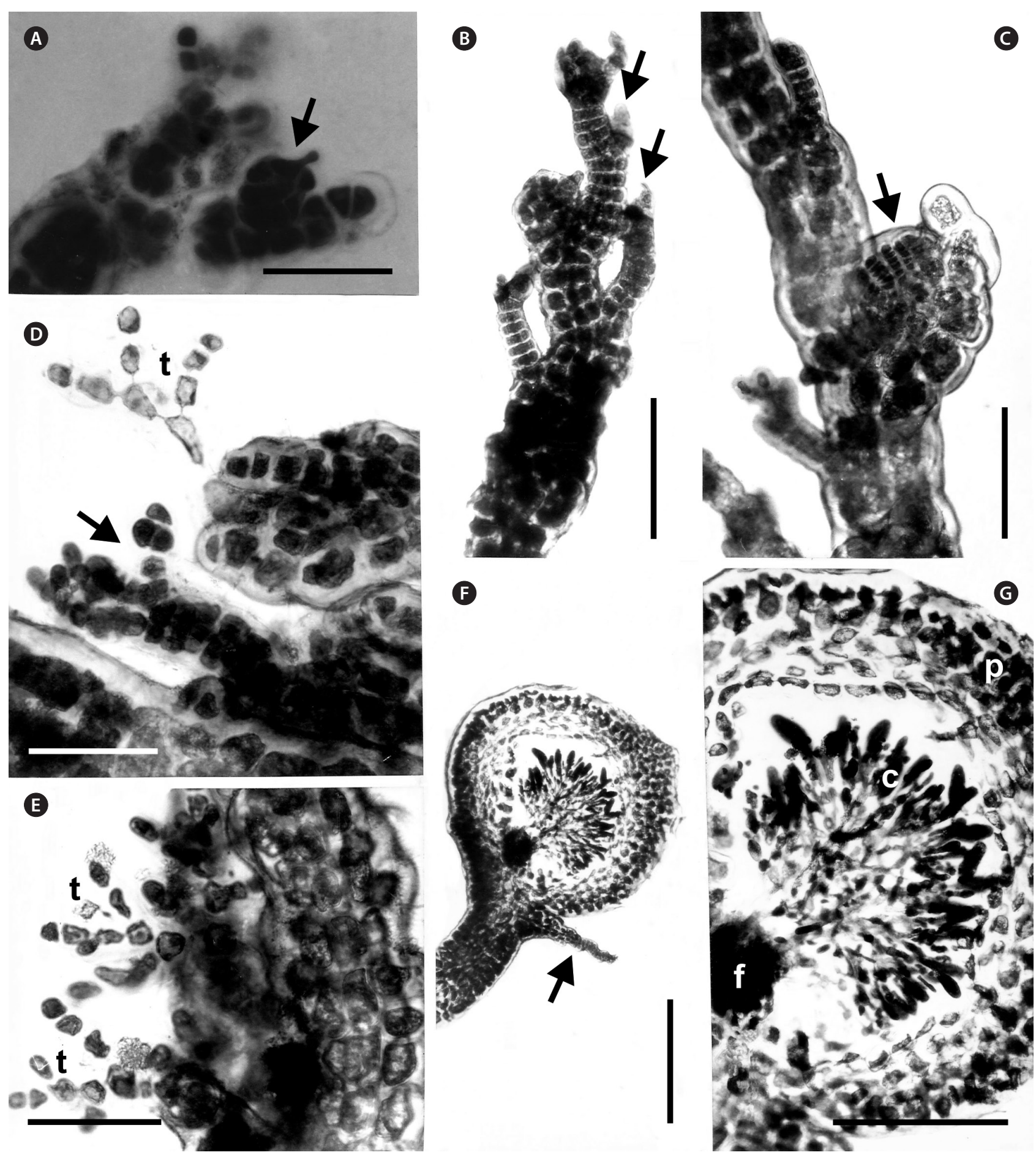

Fig. 5. Alsidium oliveiranum sp. nov. (A) Procarp with a four-celled carpogonial branch (arrow). (B) Apex of a female branch with procarps (arrows). (C) Apex of a female plant with a young cystocarp (arrow). (D) Apex of a female branch showing vegetative trichoblasts (t) and a brachyblast (arrow). (E) Apical portion of a female branch with trichoblasts ( $t$ ). ( $F \& G$ ) Longitudinal section of a cystocarp with a ligulate basal appendix (arrow), 5- to 6-cell layered pericarp (p), carposporangia (c), and a fusion cell (f). Scale bars represent: A, D \& E, $50 \mu \mathrm{m} ; \mathrm{B} \& \mathrm{C}, 100 \mu \mathrm{m} ; \mathrm{F}, 500 \mu \mathrm{m} ; \mathrm{G}, 300 \mu \mathrm{m}$. 
branches originated endogenously from axial cells and densely clustered (Fig. 4A, C \& D), corticated, cylindrical with tapered tips, $1.0-2.0 \mathrm{~mm}$ in length and $100-200$ $\mu \mathrm{m}$ in diameter (Fig. 4E), distributed sparsely along the thallus. Tetrasporangia $90-100 \mu \mathrm{m}$ in diameter formed adaxially from pericentral cells. One tetrasporangium occurred in each segment in a spiral sequence, causing swelling on the side where the spores are borne (Fig. 4E \& F). Mature tetrasporangia covered by two presporangial cover cells and elongated cortical cells.

\section{DISCUSSION}

The Brazilian species in our phylogeny nested in a clade with species of the genus Alsidium. The most distinctive morphological characters at the generic level observed in this species were as follows: (1) the thallus consists of a basal crust that produces erect axes; (2) the erect axes are cartilaginous with seven pericentral cells and are corticated beginning close to the apices; (3) spermatangial branches replace the trichoblasts and are plate-like; (4) one tetrasporangia per segment is formed on endogenous determinate branches. All of these characters are in agreement with the current delineation of the genus Alsidium (García-Soto and Lopez-Bautista 2018). Moreover, the new species is characterized by a development of the cortex that differs from Digenea, the other genus in the tribe Alsidieae. In A. oliveiranum, the formation of the cortex commences close to the apices and the first cortical cells are divided from the margins of the pericentral cells. Later, the cortex continues its development forming a continuous layer that covers the pericentral cells. Cortical development in A. oliveiranum is similar to that observed in other corticated members of the genus ( $A$. seaforthii and A. corallinum) (PD personal observation). The development of the cortex in Digenea, by contrast, is unusual compared with Alsidium and other Rhodomelaceae. The pericentral cells initially divide into discrete packets of cortical cells that cover each of the pericentral cells (Falkenberg 1901, Norris 1994, Boo et al. 2018, Schneider et al. 2018). Such pattern is conspicuous in the apical parts of Digenea cymatophila (R. E. Norris) DíazTapia \& Maggs as well as in the determinate branches of other species of Digenea (Falkenberg 1901, Norris 1994, Boo et al. 2018, Schneider et al. 2018). Later, the cortex of Digenea further develops obscuring this pattern in older parts of the thallus. Therefore, the cortical development is a useful character for delineating Alsidium from Digenea. Most species in Digenea share a common and distinctive habit, as the main axes are densely clothed with short determinate branches. However, the habit of $D$. cymatophila, with scarce determinate branches, differs from other congeners and resembles Alsidium. In fact, $D$.

Table 1. Comparison of key morphological characters for distinguishing Alsidium oliveiranum and congeneric species (except $A$. vagum whose morphology is largely unknown as its brief protologue provides the only available information)

\begin{tabular}{|c|c|c|c|c|c|c|c|}
\hline & $\begin{array}{l}\text { Thallus } \\
\text { length } \\
\text { (cm) }\end{array}$ & $\begin{array}{c}\text { Axes } \\
\text { outline }\end{array}$ & $\begin{array}{l}\text { No. of } \\
\text { pericentral } \\
\text { cells }\end{array}$ & $\begin{array}{l}\text { Determinate } \\
\text { branches }\end{array}$ & $\begin{array}{l}\text { Branches bear- } \\
\text { ing reproductive } \\
\text { structures }\end{array}$ & $\begin{array}{l}\text { Attachment } \\
\text { system }\end{array}$ & Reference \\
\hline $\begin{array}{l}\text { A. oliveiranum } \\
\text { sp. nov. }\end{array}$ & 25 & Terete & 7 & $\begin{array}{l}\text { Scarce, forming } \\
\text { clusters irregularly } \\
\text { arranged }\end{array}$ & Clustered & Basal crust & This work \\
\hline A. corallinum & 20 & Terete & $5-8$ & $\begin{array}{l}\text { Abundant, spirally } \\
\text { arranged at regular } \\
\text { intervals }\end{array}$ & Non-clustered & Basal crust & $\begin{array}{l}\text { Kützing (1865), } \\
\text { Einav (2007), } \\
\text { Rodríguez-Prieto } \\
\text { et al. (2013) }\end{array}$ \\
\hline $\begin{array}{l}\text { A. helmintho- } \\
\text { chorton }\end{array}$ & 5 & Terete & $7-9$ & $\begin{array}{l}\text { Scarce, spirally } \\
\text { arranged at irregu- } \\
\text { lar intervals }\end{array}$ & Non-clustered & Prostrate axes & $\begin{array}{l}\text { Kützing (1865), } \\
\text { Rodríguez-Prieto } \\
\text { et al. (2013) }\end{array}$ \\
\hline A. pacificum & 1.5 & Terete & 7 & Scarce & Unknown & Prostrate axes & Dawson (1959) \\
\hline A. pusillum & 1 & Terete & 5 & Scarce & Unknown & Prostrate axes & Dawson (1963) \\
\hline A. seaforthii & 20 & Complanate & $8-9$ & $\begin{array}{l}\text { Abundant, alter- } \\
\text { nately arranged }\end{array}$ & $\begin{array}{l}\text { Non-clustered } \\
\text { or sometimes } \\
\text { clustered }\end{array}$ & $\begin{array}{l}\text { Rhizomatous } \\
\text { holdfast }\end{array}$ & $\begin{array}{l}\text { García-Soto and } \\
\text { Lopez-Bautista } \\
\text { (2018) }\end{array}$ \\
\hline A. triquetrum & 25 & $\begin{array}{r}\text { Triangular or } \\
\text { complanate }\end{array}$ & $7-9$ & $\begin{array}{l}\text { Abundant, spirally } \\
\text { arranged forming } \\
\text { three rows }\end{array}$ & $\begin{array}{l}\text { Non-clustered } \\
\text { or sometimes } \\
\text { clustered }\end{array}$ & Basal disc & $\begin{array}{l}\text { Littler and Littler } \\
\text { (2000), García-Soto } \\
\text { and Lopez-Bautista } \\
\text { (2018) }\end{array}$ \\
\hline
\end{tabular}


cymatophila was originally assigned to Alsidium (Norris 1994) and later transferred to Digenea based on its placement in phylogenetic analyses (Díaz-Tapia et al. 2017, Fig. 2 in this work). A. oliveiranum is particularly similar in outline morphology to D. cymatophila, as both species consist of a basal crust from which scarcely branched erect axes arose, and determinate branches are clustered and mainly formed in relation to reproductive structures. The cortex development is particularly useful for the generic assignment of this pair of species.

Alsidium oliveiranum clearly differs from the other three species of this genus that have been molecularly characterized (A. triquetrum, A. seaforthii, and A. corallinum) by sequence divergence $\geq 2.5$ and $4.2 \%$ in the $r b c \mathrm{~L}$ and $\operatorname{cox} 1$ genes, respectively. Moreover, they can be distinguished by their morphological characters (Table 1). A. triquetrum and A. seaforthii, formerly included in the genus Bryothamnion Kützing, have compressed or triangular thallus differing from the terete axes in A. oliveiranum (Littler and Littler 2000, García-Soto and Lopez-Bautista 2018). Likewise, A. corallinum and A. oliveiranum differ morphologically in several characters: (1) axes have 5-8 vs. 7 pericentral cells; (2) the thallus being clothed with abundant determinate branches vs. determinate branches being scarce and mainly produced in relation to reproductive structures; and (3) tetrasporangia forming in non-clustered vs. clustered lateral determinate branches (Kützing 1865, Rodríguez-Prieto et al. 2013).

Other four species are currently recognized in the genus Alsidium (Guiry and Guiry 2019), but molecular data are unavailable at present. Alsidium helminthochorton (Schwendimann) Kützing was originally described and is endemic to the Mediterranean Sea (Kützing 1865, Rodríguez-Prieto et al. 2013). Relevant differences between A. helminthochorton and A. oliveiranum include: (1) axes with 7-9 vs. 7 pericentral cells; and (2) the attachment by prostrate axes vs. a basal crust (Kützing 1865, RodríguezPrieto et al. 2013). Two very small species that differ in the number of pericentral cells, Alsidium pacificum $\mathrm{E}$. Y. Dawson and Alsidium pusillum E. Y. Dawson, were described in the Palmyra Atoll and the Galapagos Islands, respectively (Dawson 1959, 1963), and were considered conspecific by Norris (1994). Their short erect thalli (up to $15 \mathrm{~mm}$ in length) contrast with the long thalli in $A$. oliveiranum (up to $25 \mathrm{~cm}$ ). Moreover, they have a system of prostrate axes that differs from the basal crust in A. oliveiranum (Dawson 1959, 1963). Finally, Alsidium vagum (Zanardini) Zanardini was described from the Mediterranean Sea and was not recorded after its original description (Guiry and Guiry 2019). Such description did not provide morphological details enough to ascertain its identity and further studies are required to clarify its taxonomy (Zanardini 1851, Bompard 1867). Therefore, our molecular and morphological studies clearly distinguish the Brazilian species from previously described species in the genus Alsidium and consequently we erected the new species A. oliveiranum here.

In Brazil, two species of Alsidium were traditionally reported based on morphological studies: A. seaforthii and A. triquetrum. Both are distributed from the Atlantic North America to Brazil (Guiry and Guiry 2019). A. oliveiranum has a much narrower distribution and is endemic to the states of Espírito Santo and Rio de Janeiro; despite our sampling efforts, it was not found elsewhere. In Brazil, A. seaforthii has the widest range, extending southward to the coast of São Paulo, while A. triquetrum is restricted to the northeastern coast (up to Bahia). A. oliveiranum and A. seaforthii occur sympatrically on the Espírito Santo and Rio de Janeiro (Guimarães 2006). This result is unsurprising, as this region hosts a particularly high algal species diversity, including rare and endemic species (De Oliveira Filho 1969, Guimarães and Fujii 1998, Chen et al. 2019). Moreover, its seaweed diversity is continuously growing as the use of molecular assisted identification is contributing to the discovery of new species (Nauer et al. 2015, Iha et al. 2016, Ximenes et al. 2017, Brunelli et al. 2019a, 2019b). The high diversity in this peculiar coast has been attributed to the substrate heterogeneity and availability, as well as the particular seawater temperature conditions because this region is a transition zone between tropical and subtropical regions and it is affected by upwelling events (Guimarães 2003).

Our finding contributes to better understand the diversity of the genus Alsidium and the tribe Alsidieae. This tribe, with 15 recognized species, has a reduced species diversity compared with other tribes in the Rhodomelaceae and most species have restricted distributions in tropical and subtropical coasts: the Mediterranean and Macaronesian Islands (A. corallinum and A. helminthochorton), Pacific Islands (A. pusillum, A. pacificum, and Digenea cymathophyla), the Pacific and Atlantic coasts of the Americas (A. seaforthii, A. triquetrum, "Bryothamnion" pacificum W. R. Taylor) and South Africa (D. subarticulata Simons) (Guiry and Guiry 2019). Digenea simplex (Wulfen) C. Agardh is the only species of the tribe that has been widely reported in tropical and subtropical coasts worldwide (Guiry and Guiry 2019). However, the sequencing of material from the type locality, the Mediterranean Sea, led to the discovery of cryptic diversity within what had been referred to as D. simplex in the 
Americas where three new species have been segregated recently from D. simplex (Boo et al. 2018, Schneider et al. 2018). Interestingly, the Atlantic and Pacific coasts of America, with six currently recognized species, host the largest diversity of species of the tribe Alsidieae.

In conclusion, in this paper we described a new species of Alsidium endemic to Brazil, a species that was previously overlooked because of the lack of study of its intertidal habitat on sand-covered rocks. Interestingly, this is also the typical habitat for other species of the tribe Alsidieae (e.g., Boo et al. 2018, Schneider et al. 2018). Our work contributes to better understand the species and morphological diversity of the tribe Alsidieae.

\section{ACKNOWLEDGEMENTS}

We are very grateful to Dr. Max Hommersand (University of North Carolina) for providing us with helpful comments and suggestions to a previous version of this manuscript. PDT acknowledges support to the postdoctoral program "Axudas de apoio á etapa de formación posdoutoral" and grant GPC2015/025 of the Xunta de Galicia. MTF thanks the Conselho Nacional de Desenvolvimento Científico e Tecnológico (CNPq) for the Productivity Fellowship (304899/2017-8). This study was partially funded by the Fundação de Amparo à Pesquisa do Estado de São Paulo (FAPESP 2016/50370-7).

\section{SUPPLEMENTARY MATERIALS}

Supplementary Table S1. GenBank accession numbers and collection information of the sequences used in phylogenetic analyses (https://www.e-algae.org).

\section{REFERENCES}

Airoldi, L. 2003. The effects of sedimentation on rocky coast assemblages. Oceanogr. Mar. Biol. Ann. Rev. 41:161-236.

Bárbara, I., Choi, H. -G., Secilla, A., Díaz-Tapia, P., Gorostiaga, J. M., Seo, T. -K., Jung, M. -Y. \& Berecibar, E. 2013. Lampisiphonia iberica gen. et sp. nov. (Ceramiales, Rhodophyta) based on morphology and molecular evidence. Phycologia 52:137-155.

Bompard, H. 1867. Algae novae ditionis genuensis. Hedwigia 9:129-130

Boo, G. H., Robledo, D., Andrade-Sorcia, G. \& Boo, S. M. 2018. Genetic discontinuity of Digenea (Rhodomela- ceae, Rhodophyta) from Mexico supports recognition of two new species, D. mexicana and D. rafaelii. Algae 33:231-241.

Brunelli, B., Jamas, M., Milstein, D., Boo, S. M. \& Fujii, M. T. 2019a. Gelidium brasiliense sp. nov. (Gelidiales, Rhodophyta): a diminutive agarophyte from Brazil. J. Appl. Phycol. 31:951-958.

Brunelli, B., Milstein, D., Boo, S. M. \& Fujii, M. T. $2019 b$. Gelidium guimaraesiae sp. nov. (Gelidiaceae, Rhodophyta) from the western Atlantic segregated from $G$. floridanum by morphological and molecular evidence. Phytotaxa 388:275-286.

Chen, D. H., Soares, L. P. \& Fujii, M. T. 2019. Molecular and morphological reappraisal of Spyridiocolax capixabus (Spyridiaceae, Rhodophyta), a rare endemic parasite from Brazil. Bot. Mar. 62:345-353.

D’Archino, R., Nelson, W., Yang, M. Y. \& Kim, M. S. 2015. New record of Hypnea flexicaulis in New Zealand and description of Calliblepharis psammophilus sp. nov. Bot. Mar. 58:485-497.

Dawson, E. Y. 1959. Changes in Palmyra Atoll and its vegetation through the activities of man, 1913-1958. Pac. Nat. 1:3-51.

Dawson, E. Y. 1963. New records of marine algae from the Galapagos Islands. Pac. Nat. 4:3-23.

De Oliveira Filho, E. C. 1969. A new species of Calliblepharis from Brazil. Nova Hedwigia 18:769-774.

Díaz-Tapia, P. \& Bárbara, I. 2013. Seaweeds from sand-covered rocks of the Atlantic Iberian Peninsula. Part. 1. The Rhodomelaceae (Ceramiales, Rhodophyta). Cryptogam. Algol. 34:325-422.

Díaz-Tapia, P., Bárbara, I. \& Díez, I. 2013a. Multi-scale spatial variability in intertidal benthic assemblages: differences between sand-free and sand-covered rocky habitats. Estuar. Coast. Shelf Sci. 133:97-108.

Díaz-Tapia, P., Boo, S. M., Geraldino, P. J. L., Maneiro, I., Bárbara, I. \& Hommersand, M. H. 2013b. Morphology and systematics of Calliblepharis hypneoides, sp. nov. (Cystocloniaceae, Rhodophyta) from the Atlantic Iberian Peninsula. Eur. J. Phycol. 48:380-397.

Díaz-Tapia, P., Maggs, C. A., Macaya, E. C. \& Verbruggen, H. 2018. Widely distributed red algae often represent hidden introductions, complexes of cryptic species or species with strong phylogeographic structure. J. Phycol. 54:829-839.

Díaz-Tapia, P., Maggs, C. A., West, J. A. \& Verbruggen, H. 2017. Analysis of chloroplast genomes and a supermatrix inform reclassification of the Rhodomelaceae (Rhodophyta). J. Phycol. 53:920-937.

Einav, R. 2007. Seaweeds of the eastern Mediterranean coast. 
A.R.G. Gantner Verlag K.G., Ruggell Press, Liechtenstein, $266 \mathrm{pp}$.

Falkenberg, P. 1901. Die Rhodomelaceen des Golfes von Neapel und der angrenzenden Meeres-Abschnitte. Fauna und Flora des Golfes von Neapel, Monographie 26. Koeltz Scientific Books, Berlin, 754 pp.

Freshwater, D. W. \& Rueness, J. 1994. Phylogenetic relationships of some European Gelidium (Gelidiales, Rhodophyta) species based upon $r b c \mathrm{~L}$ nucleotide sequence analysis. Phycologia 33:187-194.

García-Soto, G. \& Lopez-Bautista, J. 2018. Taxonomic notes on the genus Alsidium C. Agardh, including the merging of Bryothamnion Kützing (Rhodomelaceae). Algae 33:215-229.

Guimarães, S. M. P. B. 2003. Uma análise da diversidade da flora marinha bentônica do estado do Espírito Santo, Brasil. Hoehnea 30:11-19.

Guimarães, S. M. P. B. 2006. A revised checklist of benthic marine Rhodophyta from the State of Espírito Santo, Brazil. Bol. Inst. Bot. 17:143-194.

Guimarães, S. M. P. B. \& Fujii, M. T. 1998. Two species of foliose Halymenia (Halymeniaceae, Rhodophyta) from Brazil. Bot. Mar. 41:495-504.

Guiry, M. D. \& Guiry, G. M. 2019. AlgaeBase. World-wide electronic publication, National University of Ireland, Galway. Available from: http://www.algaebase.org. Accessed Jan 5, 2019.

Iha, C., O'Shaughnessy, K. A., Guimarães, S. M. P. B., Oliveira, M. C. \& Freshwater, D. W. 2016. Taxonomic reappraisal of Gelidium coarctatum (Gelidiales, Rhodophyta) and Gelidium lineare sp. nov. from the tropical western Atlantic. Phycologia 55:555-563.

Kearse, M., Moir, R., Wilson, A., Stones-Havas, S., Cheung, M., Sturrock, S., Buxton, S., Cooper, A., Markowits, S., Duran, C., Thierer, T., Ashton, B., Meintjes, P. \& Drummond, A. 2012. Geneious Basic: an integrated and extendable desktop software platform for the organization and analysis of sequence data. Bioinformatics 28:16471649.

Kim, B. \& Kim, M. S. 2014. Three new species of Polysiphonia sensu lato (Rhodophyta) based on the morphology and molecular evidence. Algae 29:183-195.

Kützing, F. T. 1865. Tabulae phycologicae: oder, Abbildungen der Tange. Vol. XV. Gedruckt auf Kosten des Verfassers, Nordhausen, $36 \mathrm{pp}$.

Le Gall, L. \& Saunders, G. W. 2010. DNA barcoding is a powerful tool to uncover red algal diversity: a case study of the Phyllophoraceae (Gigartinales, Rhodophyta) in the Canadian flora. J. Phycol. 46:374-389.

Littler, D. S. \& Littler, M. M. 2000. Caribbean reef plants: an identification guide to the reef plants of the Caribbean, Bahamas, Florida and Gulf of Mexico. Offshore Graphics, Washington, DC, 542 pp.

Maggs, C. A. \& Hommersand, M. H. 1993. Seaweeds of the British Isles. Vol. 1. Rhodophyta. Part 3A. Ceramiales. Natural History Museum, Pelagic Publishing, London, 444 pp.

Mamoozadeh, N. R. \& Freshwater, D. W. 2011. Taxonomic notes on Caribbean Neosiphonia and Polysiphonia (Ceramiales, Florideophyceae): five species from Florida, USA and Mexico. Bot. Mar. 54:269-292.

Muangmai, N., von Ammon, U. \& Zuccarello, G. C. 2016. Cryptic species in sympatry: nonrandom small-scale distribution patterns in Bostrychia intricata (Ceramiales, Rhodophyta). Phycologia 55:424-430.

Nauer, F., Cassano, V. \& Oliveira, M. C. 2015. Description of Hypnea pseudomusciformis sp. nov., a new species based on molecular and morphological analyses, in the context of the H. musciformis complex (Gigartinales, Rhodophyta). J. Appl. Phycol. 27:2405-2417.

Norris, R. E. 1994. Some cumophytic Rhodomelaceae (Rhodophyta) occurring in Hawaiian surf. Phycologia 33:434-443.

Rodríguez-Prieto, C., Ballesteros, E., Boisset, F. \& AfonsoCarrillo, J. 2013. Guía de las macroalgas y fanerógamas marinas del Mediterráneo occidental. Ediciones Omega, S.A., Barcelona, 656 pp.

Saunders, G. W. 2005. Applying DNA barcoding to red macroalgae: a preliminary appraisal holds promise for future applications. Philos. Trans. R. Soc. Lond. B Biol. Sci. 360:1879-1888.

Saunders, G. W. 2008. A DNA barcode examination of the red algal family Dumontiaceae in Canadian waters reveals substantial cryptic species diversity. 1. The foliose Dilsea-Neodilsea complex and Weeksia. Botany 86:773-789.

Saunders, G. W. \& McDevit, D. C. 2012. Methods for DNA barcoding of photosynthetic protists emphasizing the macroalgae and diatoms. Methods Mol. Biol. 858:207-222.

Saunders, G. W. \& Moore, T. E. 2013. Refinements for the amplification and sequencing of red algal DNA barcode and RedToL phylogenetic markers: a summary of current primers, profiles and strategies. Algae 28:31-43.

Savoie, A. M. \& Saunders, G. W. 2016. A molecular phylogenetic and DNA barcode assessment of the tribe Pterosiphonieae (Ceramiales, Rhodophyta) emphasizing the Northeast Pacific. Botany 94:917-939.

Schneider, C. W., Hamzeh, B. F., Lane, C. E. \& Saunders, G. W. 2018. A new species of Digenea (Rhodomelaceae, Ceramiales) based upon a molecular assessment and morphological observations of plants historically known as 
D. simplex in Bermuda. Phytotaxa 338:90-98.

Stamatakis, A. 2014. RAxML version 8: a tool for phylogenetic analysis and post-analysis of large phylogenies. Bioinformatics 30:1312-1313.

Womersley, H. B. S. 2003. The marine benthic flora of southern Australia - Part IIID Ceramiales - Delesseriaceae, Sarcomeniaceae, Rhodomelaceae. Australian Biological Resources Study and State Herbarium of South Australia, Canberra and Adelaide, 533 pp.

Ximenes, C. F., Cassano, V., de Oliveira-Carvalho, M. F., Bandeira-Pedrosa, M. E., Gurgel, C. F. D., Verbruggen, H. \&
Pereira, S. M. B. 2017. Systematics of the genus Halimeda (Bryopsidales, Chlorophyta) in Brazil including the description of Halimeda jolyana sp. nov. Phycologia 56:369-381.

Zanardini, G. 1851. Algae novae vel minus cognitae in mari Rubro a Portiero collectae. Flora 34:33-38.

Zuccarello, G. C., Muangmai, N., Preuss, M., Sanchez, L. B., Loiseaux de Goër, S. \& West, J. A. 2015. The Bostrychia tenella species complex: morphospecies and genetic cryptic species with resurrection of $B$. binderi. Phycologia 54:261-270. 